\title{
Erosional record of Himalayan uplift in the Bay of Bengal since the late Eocene
}

\author{
SHIMING WAN ${ }^{1}$, ZEHUA SONG ${ }^{1}$ AND CHRISTOPHE \\ COLIN $^{2}$ \\ ${ }^{1}$ Institute of Oceanology, Chinese Academy of Sciences \\ ${ }^{2}$ Université Paris-Saclay \\ Presenting Author: wanshiming@ms.qdio.ac.cn
}

Reconstructing the Cenozoic sedimentary history of the Bay of Bengal $(\mathrm{BoB})$ is significant for understanding the evolutionary history of South Asian river systems and the links between river development, tectonic deformation and global climate change. Here, we present the first long-term clay mineral record combined with $\mathrm{Sr}-\mathrm{Nd}$ isotopic compositions from a 200-m-long sediment core from Ocean Drilling Program (ODP) Site 758 in the southern $\mathrm{BoB}$ to establish past variations in sediment sources and river evolution that have occurred since the late Eocene. Provenance analysis suggests that the contribution of the Himalayan source materials from the Irrawaddy and Brahmaputra Rivers to the study site became more important and stable since $22 \mathrm{Ma}$ and $8 \mathrm{Ma}$, respectively. This new evidence indicates that the Brahmaputra and Irrawaddy Rivers were possibly initiated in the early Miocene ( $22 \mathrm{Ma})$. Considering the timing of major tectonic and climatic evolution in South Asia, we conclude that the two phases of tectonic uplift of the Himalayan orogen that occurred in the early and late Miocene were the primary controls on river development in South Asia and provenance changes in the southern BoB. Global cooling and Indian drying after the late Miocene could also have strengthened Himalayan erosion and contributed more illite and chlorite to the South Asian margin. 